\title{
Preliminary Exploration of Integrating Ideological and Political Education Major with Middle School Politics Lessons
}

\author{
Dongbo Zhai* \\ Chongqing Jiaotong University School of Party and Government Office, Chongqing 404100, China \\ *Corresponding author: Dongbo Zhai, zhaidongbo1985@163.com
}

Copyright: () 2022 Author(s). This is an open-access article distributed under the terms of the Creative Commons Attribution License (CC BY 4.0), permitting distribution and reproduction in any medium, provided the original work is cited.

\begin{abstract}
The ideological and political education major in colleges and universities mainly undertakes the task of cultivating teachers for middle school politics lessons. The teaching methods and curriculum need to adapt to the new curriculum reform requirements as well as the current teaching idea, teaching content, teaching means, and teaching mode, in order to realize the ideological and political education specialty and middle school politics lessons.
\end{abstract}

Keywords: Ideological and political education; Colleges and universities; Middle school politics lesson; New curriculum reform

Online publication: January 20, 2022

\section{Introduction}

Since the establishment of ideological and political education in the 1950s, the major courses, especially the main teaching contents, have maintained a relatively high stability, which is consistent with the stability of the educational policy and educational objectives of the Communist Party of China. However, with the reform of the ideological and political teaching content in middle schools, the teaching and curriculum setting of ideological and political education in colleges and universities are also facing new challenges. In view of the new situation brought by the new curriculum reform in middle schools, the teaching and curriculum setting of this major in colleges and universities must keep pace with the times.

\section{Characteristics and requirements of the new curriculum reform of middle school politics}

As the new round of scientific and technological revolution and industrial transformation deepens as well as taking education as the core, the fundamental task of fostering moral integrity and educating people should be fulfilled, the primary function of schools in educating people should be fully developed, and socialist builders and successors who are well-developed morally, intellectually, physically, aesthetically, and in labor should be trained.

\subsection{The new curriculum reform of middle school politics presents new characteristics}

The nature of the course is more prominent. It is guided by the Thought on Socialism with Chinese Characteristics for a New Era and closely linked with daily life as well as ideological practice. It focuses on cultivating students with the spirit of party building, national spirit, and excellent culture; in addition, it 
respects the laws of learning and development as well as lays a foundation for students to form correct world outlook, outlook on life, and values.

The design idea is clearer. The "Standard of Ideological and Political Curriculum for Ordinary Senior High Schools" clearly pointed out that ideological and political teaching should enhance the sense of the times, pertinence, timeliness, and initiative, while emphasizing the organic integration of knowledge, ability, and attitude ${ }^{[1]}$. This embodies the idea of taking the development of students as the foundation and the multi-dimensional dynamic educational outlook.

It is also closer to the physical and mental development of middle school students and life. Pertaining to the course content, those difficult, old, complex knowledge points have been removed. Transforming a small classroom into a big society itself reflects an ideological and political class with practical principles of the objective requirements.

\subsection{The new curriculum reform puts forward new requirements for middle school teachers}

The reform of the curriculum structure has changed the original middle school course standard and curriculum content. It targeted several phenomena, such as the lack of integration and the overburden of students from schoolwork. The modification of the curriculum structure highlights those balanced, comprehensive, and selective courses. The requirements mandate political teachers to have profound professional and discipline knowledge as well as a wide range of cultural and scientific knowledge.

From the perspective of the transformation of curriculum implementation, the change of students' learning mode is one of the key goals of the curriculum reform in China. It requires ideological and political teachers to adapt to new roles and functions. They should not only understand the general theoretical knowledge and practical principles of education and teaching, but also the psychological knowledge and the sequence as well as characteristics of students' psychological development.

From the aspect of curriculum content reform, the new curriculum advocates the addition of the new contents into elective courses. This requires teachers to broaden their academic horizon, improve their academic ability, pay attention to the latest developments of the subject, as well as integrate the latest academic ideas and cutting-edge knowledge into classroom teaching.

\section{Existing problems from the "new curriculum reform" perspective of university and middle school politics lessons}

\subsection{The characteristics of teachers are not distinct enough}

With the deepening of the reform of basic education, the diversification of the mode of running schools in high schools, and the implementation of the new curriculum plan, the teaching content and system of ideological and political courses in middle schools have undergone great changes, thus putting forward new requirements for the quality of ideology and political teachers in middle schools. At the same time, it also makes the disconnection between the ideological and political education major and the ideological and political curriculum reform in middle schools more prominent.

\subsection{Uniformity of the curriculum}

In China's colleges and universities, the single curriculum, backward concept, outdated content, and the "divorced from reality" belief have always been the main problems existing in the curriculum ${ }^{[2]}$. In most schools, same majors have the same main courses, and even the elective courses are the same, so students are bound to have no personality with a lack of innovation consciousness as a result of having a "school with the same curriculum schedule, teachers with teaching plans, and everyone with textbooks" situation. 


\subsection{The curriculum concept emphasizes theory but not practice}

The proportion of theoretical courses to practical courses is imbalance. As a result, this does not meet the requirements of a quality-oriented education, which focuses on cultivating students' innovative spirit and practical skills. It also does not meet the requirements of employers with their demand for practical skills from students upon graduation. Universities usually set a period of 4 weeks for internship, but the actual period is far less than 4 weeks; instead, students only access the platform two or three times. During internships, schools tend to lack effective supervision, even after the internship; schools are contented as long as the internship certificate is obtained.

\subsection{Teaching content and teaching methods lag behind the development of theory and practice}

From the perspective of teaching content, the current professional teaching content does not fully reflect the cutting-edge achievements of the subject development. There are many disconnections between theory and reality along with the separation of knowledge and thought as well as the lack of inspiring students to think creatively. In terms of teaching methods, the "full irrigation" phenomenon is still very common; in modern educational methods, educational technology means for development and application appear more backward.

\section{Countermeasures for the effective connection between ideological and political education in colleges and middle schools}

\subsection{Renewing the teaching concept}

The key to the new curriculum reform is the reform of educational ideas and teaching thoughts. The core problem is on how to treat the students in class and how to deal with the relationship between teachers and students. In the teaching of ideological and political education, the requirements of the new curriculum should be adopted. First of all, the original teaching ideas should be updated. Teachers need to hold on to the "student-oriented" concept, give full play to students' enthusiasm, initiative, and creativity, as well as transform their roles from teachers who excessively emphasize on theoretical knowledge to promoters of knowledge and skills, guides of independent learning, stimulators of non-intellectual factors, and helpers of students in their active growth and development.

\subsection{Integrating the teaching content}

First of all, to reflect the scientific nature of the teaching content, one of the fundamental tasks of political courses in colleges and middle schools is to carry out the Marxist theoretical education; the primary and basic characteristic of Marxism is its scientific nature. This requires teachers to treat Marxism as a science and promote the optimization of teaching content on the basis of discipline construction. Secondly, to reflect the content of the times, the quality of Marxist theories lies in keeping pace with the times. Therefore, college teachers should arm the minds of college students with developing Marxism, insist on combining theory with practice, ensure that the teaching content is close to reality, life, and the students with rich sense of the times, as well as enhance timeliness.

\subsection{Optimizing the teaching methods}

First, use modern education technology, such as multimedia, to optimize classroom teaching. With multimedia teaching through text, images, and other functions, the course content can be shared in various forms to convey educational information to students. In that way, their brains can be stimulated by various information. The creation of teaching scenes can stimulate students' learning enthusiasm in a concrete and 
visualized way as well as assist students in understanding abstract theories, so as to achieve an optimal teaching effect. Secondly, the function of microteaching classroom should be fully utilized to improve the practical effect of students' skills. In the training of teaching design, teaching videos in micro-teaching classrooms and the play-back function of micro-teaching records should be used in a timely manner to play back, decompose, and comment on the training of students.

\subsection{Innovating the teaching mode}

In teaching, the "problem discussion" teaching mode should be adopted; that is, according to the teaching content of the first question, students are encouraged to think and discuss, then the teacher will summarize and explain, so as to fully mobilize the initiative and enthusiasm of students in learning and also reflect the principle of practice. In the theoretical knowledge part of learning, teachers are more likely to relate cases or present a certain situation when explaining to deepen students' understanding of a certain knowledge point through the analyses of cases. The usual flow is as such: "problem discussion - situation analysis summary and arrangement." It is commonly seen in teaching practice that after raising questions, teachers will make preliminary summaries based on students' discussion, so that students can develop a general understanding of the teaching design and the implementation process of a specific knowledge.

\section{Conclusion}

In conclusion, for ideological and political education in colleges and universities, there is a need to ensure that the education and teaching quality standards are consistent with the new curriculum reform in middle schools, and all the administrative leaderships and administrative measures cannot replace the independent reform of various majors in colleges and universities. Divorced from the teaching practice in middle schools, the ideological and political education in colleges and universities will be far from the service object, and its teaching quality would lose significance because of this deviation.

\section{Disclosure statement}

The author declares that there is no conflict of interest.

\section{References}

[1] Ministry of Education, 2004, Ideological and Political Curriculum Standards for Ordinary Senior High Schools, People's Education Press, Beijing.

[2] Hao F, Tang R, 2007, The Reform of Teacher Education Curriculum System in Normal Universities. Education and Career, 2007(6): 56-57.

Publisher's note

Bio-Byword Scientific Publishing remains neutral with regard to jurisdictional claims in published maps and institutional affiliations. 